\title{
PENGARUH E-LEARNING SCHOOLOGY TERHADAP HASIL BELAJAR PEMROGRAMAN WEB DAN PERANGKAT BERGERAK SISWA (Studi Kasus: Kelas XI RPL di SMK Negeri 1 Negara)
}

\author{
Ni Komang Candra Sulistyawati ${ }^{1)}$, Ketut Agustini'²), Gede Aditra Pradnyana ${ }^{3)}$ \\ ${ }^{123}$ Fakultas Teknik dan Kejuruan, Universitas Pendidikan Ganesha \\ Email: candrasulistyawati@yahoo.com¹, ketutagustini@undiksha.ac.id²,gede.aditra@undiksha.ac.id³
}

\begin{abstract}
ABSTRAK
Tujuan penelitian ini untuk mengetahui (1) pengaruh e-learning schoology terhadap hasil belajar siswa mata pelajaran Pemrograman Web dan Perangkat Bergerak kelas XI RPL di SMK Negeri 1 Negara, (2) respon siswa setelah menggunakan e-learning schoology pada mata pelajaran Pemrograman Web dan Perangkat Bergerak kelas XI RPL di SMK Negeri 1 Negara. Jenis penelitian ini adalah eksperimen semu (quasi eksperimen) dengan desain Post Test Only Control Group Design. Populasi penelitian mencakup seluruh siswa kelas XI RPL di SMK Negeri 1 Negara Tahun Pelajaran 2018/2019. Sampel penelitian yang digunakan yaitu kelas XI RPL 1 sebagai kelompok kelas eksperimen dan kelas XI RPL 2 sebagai kelompok kelas kontrol dengan jumlah sampel 70 orang. Metode pengumpulan data yang digunakan yaitu metode tes dalam bentuk tes essay untuk mengetahui ranah kognitif dan metode angket atau kuesioner untuk mengetahui respon siswa. Data hasil belajar dianalisis melalui uji prasyarat yaitu meliputi uji normalitas dan uji homogenitas dengan hasil kedua kelompok berdistribusi normal dan homogen, dilanjutkan dengan uji hipotesis yang menggunakan uji t. Hasil penelitian diperoleh thitung 7,1916 yang lebih besar dari tabel 1,9955 yang menyatakan bahwa (1) terdapat perbedaan hasil belajar yang lebih tinggi antara siswa yang belajar dengan menggunakan e-learning schoology dengan siswa yang belajar dengan menggunakan power point. Hal ini dapat dilihat dari rata-rata kelompok eksperimen adalah sebesar 32,72 dan rata-rata kelompok kontrol adalah 27,56. (2) Respon siswa dari penggunaan e-learning schology pada mata pelajaran Pemrograman Web dan Perangkat Bergerak adalah sangat positif dilihat dari rata-rata skor hasil angket respon siswa yaitu 84,72.
\end{abstract}

Kata kunci: E-learning, Hasil Belajar, Pemrograman Web dan Perangkat Bergerak, Schoology

\begin{abstract}
The purpose of this study to determine (1) the impact of e-learning Schoology on student learning outcomes subjects Programming Web and Mobile Devices XI RPL in SMK 1 state, (2) the response of students after using e-learning Schoology on the subjects of Web Programming and Mobile devices in class XI RPL SMK 1 state. This type of research is quasi-experimental (quasi) with design Post Test Only Control Group Design. The study population includes all students in class XI RPL SMK 1 state in the academic year 2018/2019. The sample used is a class XI RPL as a class 1 and class XI RPL experiment as a class 2 control with a sample of 70 people. Data collection method used is the method of the test in the form of essay tests to determine cognitive and questionnaire or questionnaires to determine the students' responses. Data were analyzed through the test of learning outcomes prerequisites which include tests of normality and homogeneity tests with the results of both groups were normally distributed and homogeneous, followed by a hypothesis test using $t$ test. Results showed a greater $t 7.1916$ from 1.9955 ttable stating that (1) there are differences in learning outcomes are higher among students who learn to use e-learning Schoology with students learning by using power point. It can be seen from the average of the experimental group was 32.72 and the average of the control group was 27.56. (2) Student responses from the use of e-learning on subjects schology Programming Web and Mobile Devices is a very positive views of an average score of student questionnaire responses result is 84.72 .
\end{abstract}

Keywords: E-learning, Learning Outcomes, Web Programming and Mobile Devices, Schoology 


\section{PENDAHULUAN}

Belajar adalah suatu proses perubahan dari dalam kepribadian manusia dan perubahan tersebut ditampakkan dalam bentuk peningkatan kualitas dan kuantitas tingkah laku seperti peningkatan kecakapan, pengetahuan, sikap, kebiasaan, pemahaman, keterampilan, daya pikir, dan lain-lain [1]. Proses kegiatan pembelajaran di sekolah menuntut siswa untuk memiliki peran yang lebih aktif dan guru hanyalah sebagai pembimbing dan pengarah, selain itu pembelajaran yang telah dilaksanakan memiliki tujuan pencapaian akhir yang disebut dengan hasil belajar.

Proses pembelajaran memerlukan beberapa komponen yang dapat mempengaruhi hasil belajar salah satu diantaranya adalah media pembelajaran. Media pembelajaran adalah segala sesuatu yang dapat menyalurkan pesan, dapat merangsang pikiran, perasaan, dan kemauan peserta didik [2]. Penggunaan media pembelajaran yang tepat dapat menimbulkan sikap aktif dan semangat belajar anak didik.

Berdasarkan hasil observasi awal dengan teknik wawancara dengan guru pengampu mata pelajaran Pemrograman Web dan Perangkat Bergerak mengatakan bahwa permasalahan yang terjadi saat proses pembelajaran yaitu siswa sering tidak fokus dalam menerima pelajaran dan sering merasa bingung dalam memahami materi pelajaran ini dikarenakan kurang memadainya bahan ajar yang digunakan saat proses pembelajaran. Sumber belajar ataupun bahan ajar yang digunakan pada saat kegiatan belajar mengajar hanyalah materi yang diperoleh dari internet, sehingga siswa cenderung malas untuk mempelajari kembali materi yang telah diajarkan oleh guru, begitupun saat pertemuan selanjutnya siswa sering lupa tentang materi yang telah diberikan oleh guru pada pertemuan sebelumnya. Selain bahan ajar kendala yang terjadi saat pembelajaran yaitu kekurangan waktu mengajar, sedangkan tujuan pembelajaran yang harus dicapai peserta didik hingga akhir semester cukup banyak. Terlebih lagi SMK Negeri 1 Negara merupakan sekolah menengah kejuruan yang terletak di Desa Baler Bale Agung, Kec. Negara, Kab. Jembrana. Kurikulum yang diterapkan di sekolah ini adalah Kurikulum 2013, yang di dalamnya terdapat beberapa program yang diterapkan, salah satunya ialah program praktek kerja industri (prakerin) diwajibkan untuk siswa yang menduduki kelas XI, sehingga siswa dituntut untuk belajar secara mandiri.

Dilihat dari hasil observasi yang dilakukan di SMK Negeri 1 Negara terdapat masih banyak nilai siswa berada dibawah KKM hal ini disebabkan karena siswa kurang mengerti dengan pelajaran ini. KKM untuk mata pelajaran Pemrograman Web dan Perangkat Bergerak yaitu 75. Hal tersebut dilihat dari nilai rata-rata Ulangan Tengah Semester (UTS) yang dicapai siswa kelas XI RPL semester ganjil pada tahun pelajaran 2018/2019. Nilai siswa yang mencapai KKM sebanyak 39 orang dengan tingkat persentase sebanyak $36,79 \%$ dan siswa yang nilainya tidak mencapai KKM sebanyak 67 orang dengan tingkat persentase $63,21 \%$. Hal ini menandakan bahwa hasil belajar siswa pada mata pelajaran Pemrograman Web dan Perangkat Bergerak masih ada siswa yang belum mencapai KKM sehingga perlu dilakukan perhatian dan bimbingan lebih lanjut.

Berdasarkan permasalahan-permasalahan yang sudah dijelaskan sebelumnya, terlihat bahwa bahan ajar dan media pembelajaran berperan penting dalam proses pembelajaran. Bahan ajar sangat penting karena tanpa bahan ajar guru akan sulit meningkatkan efektivitas pembelajaran, dan siswa menjadi sulit menyesuaikan diri saat belajar, apalagi jika gurunya mengajarkan materi dengan cepat dan kurang jelas mereka dapat kehilangan jejak tanpa mampu menelusuri kembali apa yang telah diajarkan oleh guru [3]. Media pembelajaran yang bersifat monoton menyebabkan sebagian siswa merasa bosan dan cenderung hanya sekedar mendengarkan penjelasan dari guru, untuk itu media pembelajaran yang digunakan saat proses belajar mengajar sangatlah besar pengaruhnya dalam membantu proses pembelajaran. Sebagai seorang pendidik utama guru tentunya harus dapat memberikan rujukan pembelajaran secara tepat. Salah satu media yang dapat dijadikan alternatif untuk proses pembelajaran adalah dengan menggunakan sistem pembelajaran elektronik atau $e-$ learning [4].

E-learning berarti pembelajaran dengan menggunakan jasa bantuan perangkat elektronika, yang memanfaatkan teknologi komputer, jaringan komputer dan/atau internet [5]. Ciri pembelajaran dengan e-learning adalah terciptanya lingkungan belajar yang flexible. Terlebih lagi Gubernur Bali telah menghimbau seluruh SMA/SMK yang ada di Bali untuk menerapkan e-learning sebagai kelas maya untuk proses pembelajaran. Penerapan e-learning dapat memberikan pengalaman yang menarik dan bermakna bagi siswa karena dapat berinteraksi langsung, sehingga pemahaman terhadap materi akan lebih bermakna, mudah dipahami dan diingat [6]. Kelebihan schoology dibandingkan dengan edmodo, yaitu pada schoology dilengkapi dengan fasilitas absensi yang digunakan untuk mengecek kehadiran siswa, serta fasilitas untuk melihat semua aktivitas siswa pada setiap course, assignment, discussion, dan aktivitas lain yang kita siapkan untuk siswa [7]. Disamping memilih media pembelajaran seorang guru harus memilih model pembelajaran yang tepat dan kreatif, hal ini sangat penting untuk menciptakan suasana belajar yang menyenangkan bagi siswa agar dapat 
meningkatkan hasil belajar siswa. Model pembelajaran berbasis proyek atau Project Based Learning (PjBL) merupakan salah satu model pembelajaran inovatif yang dapat mendukung proses pembelajaran aktif kepada peserta didik.

Ryki Saputra telah mengembangkan sebuah e-modul dengan e-learning schoology berbasis Project Based Learning sebagai media pendukung pembelajaran photography, dimana modul ini dikembangkan dengan menggunakan model pengembangan ADDIE. Hasil penelitian yang diperoleh adalah e-modul dengan model project based learning dinyatakan berhasil diterapkan berdasarkan beberapa uji yang dilakukan. Hasil penelitian menunjukkan bahwa hasil analisis respon guru menunjukkan bahwa didapatkan respon guru yang dinyatakan sangat positif. Kemudian, berdasarkan analisis respon siswa didapatkan respon siswa yang dinyatakan positif . Selanjutnya berdasarkan hasil pengujian ahli isi, ahli desain dan ahli media pembelajaran didapatkan hasil bahwa media pembelajaran e-modul layak digunakan dalam pembelajaran.

Berdasarkan hal tersebut, maka penulis tertarik untuk mencoba menerapkan media pembelajaran e-learning schoology pada mata pelajaran Pemrograman Web dan Perangkat Bergerak di SMK Negeri 1 Negara dengan model pembelajaran Project Based Learning (PjBL) dengan melaksanakan penelitian yang berjudul "Pengaruh E-Learning Schoology Terhadap Hasil Belajar Pemrograman Web Dan Perangkat Bergerak Siswa (Studi Kasus: Kelas XI RPL Di SMK Negeri 1 Negara)". Penelitian ini bertujuan untuk mengetahui (1) pengaruh e-learning schoology terhadap hasil belajar siswa mata pelajaran Pemrograman Web dan Perangkat Bergerak kelas XI RPL di SMK Negeri 1 Negara, (2) respon siswa setelah menggunakan e-learning schoology pada mata pelajaran Pemrograman Web dan Perangkat Bergerak kelas XI RPL di SMK Negeri 1 Negara. Hasil penelitian diharapkan dapat memberikan manfaat positif dalam penggunaan media pembelajaran. Adapun manfaat dari penelitian ini (1) manfaat teoritis yaitu pada penelitian ini diharapkan dapat menambah ilmu pengetahuan dalam meningkatkan kualitas pembelajaran dengan menggunakan media dan model pembelajaran yang lebih inovatif, dimana media pembelajaran tersebut adalah e-learning schoology dan model pembelajarannya adalah Project Based Learning (PjBL), media dan model pembelajaran tersebut dapat digunakan siswa belajar secara mandiri yang dapat membantu meningkatkan kompetensi kognitif, (2) manfaat praktis yaitu pada penelitian ini diharapkan dapat memberikan pengetahuan dan pengalaman belajar baru kepada guru dan siswa, dapat memberikan kontribusi kepada sekolah dalam upaya meningkatkan kualitas pendidikan belajar siswa melalui media pembelajaran e-learning schoology dalam kegiatan pembelajaran, serta diharapkan dapat menambah pengetahuan peneliti dalam berbagai hal khusus mengenai penerapan e-learning schoology.

\section{METODE}

Penelitian ini memiliki tahapan prosedur seperti pada Gambar 1 berikut.

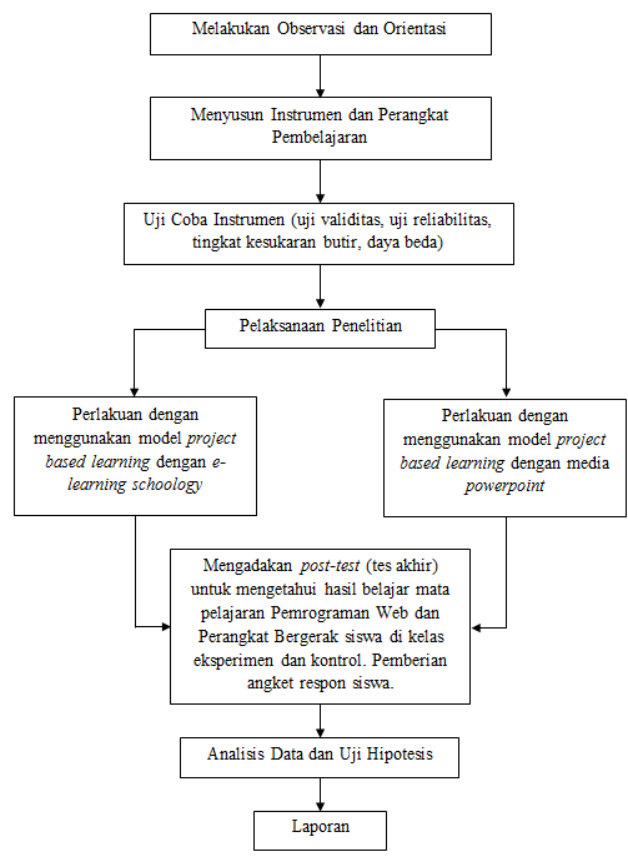

Gambar 1. Tahapan Prosedur Penelitian 
Pada Gambar 1 dapat dijelaskan bahwa penelitian ini melalui beberapa tahapan dimulai dari observasi dan orientasi masalah untuk mengetahui permasalahan yang ada dilapangan, selanjutnya dapat dilanjutkan dengan menyusun instrumen penelitian serta melakukan uji coba terhadap instrumen penelitian. Jenis penelitian eksperimen yang digunakan yaitu penelitian quasi experimental (eksperimen semu) karena pada kenyataannya tidak semua variable dan kondisi eksperimen dapat diatur serta dikontrol secara ketat [8]. Penelitian ini diberikan perlakuan yang berbeda kepada kedua kelas yaitu kelas eksperimen dengan jumlah siswa 36 orang yang diberikan perlakuan berupa media e-learning schoology dan kelas kontrol dengan jumlah siswa 34 orang yang diberikan perlakuan media pembelajaran power point. Penelitian ini dilaksanakan di SMK Negeri 1 Negara, yang menjadi subjek sampel adalah siswa kelas XI RPL pada semester II.

Desain penelitian yang digunakan yaitu Posttest Only Control Group Design. Pemilihan desain penelitian posttest only group design karena pada penelitian ini pemberian tes dilakukan setelah akhir proses pembelajaran, selain itu pada penelitian ini hasil belajar siswa yang dibandingkan adalah hasil belajar siswa setelah mengikuti proses pembelajaran antara kelas eksperimen dan kelas kontrol. Pemberian perlakuan hanya dilakukan terhadap kelas eksperimen. Metode dan instrument pengumpulan data pada penelitian ini adalah metode tes dengan menggunakan instrumen tes essay. Sebelum menentukan soal-soal yang digunakan, terlebih dahulu dilakukan uji Validitas Isi dengan menggunakan formula Gregory dengan rumus sebagai berikut [9].

Keterangan :

$$
\text { Validitas Isi }=\frac{D}{A+B+C+D}
$$

$A$ = sel yang menunjukkan ketidaksetujuan antara kedua penilai

$\mathrm{B}$ dan $\mathrm{C}=$ sel yang menunjukkan perbedaan pandangan antara penilai

$\mathrm{D}$ = sel yang menunjukkan persetujuan yang valid

Setelah dilakukan uji validitas isi oleh dua judges, didapatkan nilai 1,00 yang tergolong Sangat Tinggi. Maka, langkah selanjutnya yang dilakukan adalah uji Validitas Konstruk dengan rumus sebagai barikut.

Keterangan:

$$
r_{x y}=\frac{N \sum X Y-\left(\sum X\right)(\Sigma Y)}{\sqrt{\left\{N \sum X^{2}-(\Sigma X)^{2}\right\}\left\{N \sum Y^{2}-\left(\sum Y\right)^{2}\right\}}}
$$

$r_{\mathrm{xy}} \quad=$ koefisien korelasi product moment

$\mathrm{X} \quad$ = skor yang diperoleh siswa pada tiap butir soal

$\mathrm{Y} \quad=$ skor total yang diperoleh siswa

$\mathrm{N} \quad$ = banyak responden atau siswa

Dari uji coba validitas yang dilakukan pada 35 responden, didapat 18 butir soal yang valid. Selanjutnya adalah uji Reliabilitas dengan rumus sebagai berikut [10].

Keterangan:

$$
r_{11}=\left(\frac{k}{k-1}\right)\left(1-\frac{\sum \sigma b^{2}}{\sum \sigma t^{2}}\right)
$$

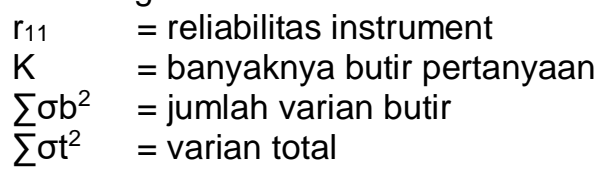

Berdasarkan hasil analisis reliabilitas tes hasil belajar Pemrograman Web dan Perangkat Bergerak siswa dengan menggunakan formula Alpha Cronbach didapatkan angka reliabilitas sebesar $r_{11}=0,79224$ dengan butir item soal sebanyak 18 dan berkualifikasi tinggi Jadi instrument tersebut layak dan dapat dipercaya untuk digunakan sebagai alat pengumpulan data. Selanjutnya adalah uji Indeks Daya Beda dengan rumus sebagai berikut [10].

$$
\mathrm{d}=\frac{(n+1)\left(N^{2}-\sum f_{i}^{2}\right)}{n N^{2}}
$$

Keterangan:

$$
\begin{array}{ll}
\mathrm{d} & =\text { indeks daya beda } \\
\mathrm{N} & =\text { banyak peserta tes } \\
\mathrm{Fi} & =\text { frekuensi pada tiap tiap skor } \\
\mathrm{N} & =\text { banyak butir }
\end{array}
$$


Berdasarkan hasil analisis diperoleh sebanyak 16 butir soal termasuk kategori sangat baik, 12 butir soal termasuk kategori baik, dan tidak ada butir soal yang memiliki kategori cukup, jelek dan sangat jelek. Langkah selanjutnya adalah uji Indeks Kesukaran Butir dengan rumus sebagai berikut [10].

$$
\mathrm{I}=\frac{\sum U+\sum L-\left(2 N * S_{\min }\right)}{2 N\left(S_{\operatorname{maks}}-S_{\min }\right)}
$$

Keterangan:

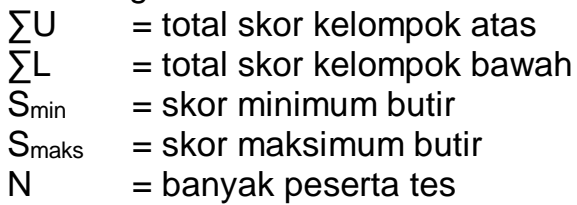

Berdasarkan hasil uji tingkat kesukaran butir diketahui 15 butir soal tergolong kategori sedang, 3 butir soal tergolong kategori mudah dan tidak ada butir soal yang berkategori sukar. Penjelasan singkat langkah-langkah di dalam menentukan distribusi frekuensi adalah sebagai berikut [11].

1. Teknik Analisis Deskriptif

Rumus yang digunakan untuk menghitung rata-rata, varians dan standar deviasi adalah sebagai berikut.

a. Rata-Rata

$$
\bar{X}=\frac{\sum \mathrm{FiXi}}{\sum \mathrm{Fi}}
$$

Keterangan:

$\bar{X} \quad=$ mean

$\mathrm{Xi} \quad=$ nilai tengah kelas interval

$\mathrm{Fi} \quad=$ frekuensi data pada kelas $\mathrm{Xi}$

b. Varians

$$
\mathrm{S}^{2}=\frac{\sum F i(X i-X)^{2}}{n-1}
$$

Keterangan:

$\mathrm{S}^{2} \quad=$ varian

$\mathrm{Xi} \quad=$ nilai tengah kelas interval

$\mathrm{Fi} \quad=$ frekuensi yang sesuai dengan $\mathrm{Xi}$

$\mathrm{X}=$ mean

$\mathrm{N} \quad$ = banyak siswa

c. Standar Deviasi

$$
S=\sqrt{S^{2}}
$$

Keterangan:

$$
\begin{array}{ll}
\mathrm{S}^{2} & =\text { standar deviasi } \\
\mathrm{S}^{2} & =\text { varian }
\end{array}
$$

Data skor posttest kemudian dikategorikan sesuai dengan pedoman pada Tabel 1 berikut. Tabel 1. Kategori Skor Posttest

\begin{tabular}{cc}
\hline Rentang Skor & Kategori \\
\hline $\mathrm{Mi}+1,5 \mathrm{Sdi} \leq \bar{X}$ & Sangat Tinggi \\
$\mathrm{Mi}+0,5 \mathrm{Sdi} \leq \bar{X}<\mathrm{Mi}+1,5 \mathrm{Sdi}$ & Tinggi \\
$\mathrm{Mi}-0,5 \mathrm{Sdi} \leq \bar{X}<\mathrm{Mi}+0,5 \mathrm{Sdi}$ & Sedang \\
$\mathrm{Mi}-1,5 \mathrm{Sdi} \leq \bar{X}<\mathrm{Mi}-0,5 \mathrm{Sdi}$ & Rendah \\
$\bar{X}<\mathrm{Mi}-0,5 \mathrm{Sdi}$ & Sangat Rendah \\
\hline
\end{tabular}

\section{Teknik Uji Prasyarat Analisis}

Data hasil penelitian dianalisis dengan uji-t. Syarat yang harus dipenuhi dalam uji-t meliputi (1) data berdistribusi normal dan (2) varians dalam kelompok homogeny. Sebelum dianalisis, terlebih dahulu dilakukan uji prasyarat. Uji prasyarat ini dilakukan untuk membuktikan bahwa data yang dikumpulkan layak untuk dianalisis dengan statistik parametrik atau tidak. Terkait dengan statistik yang digunakan untuk analisis data dalam penelitian ini, maka uji prasyarat yang dilakukan adalah uji normalitas dan uji homogenitas dengan menggunakan SPSS 16.0 dengan angka signifikan yang lebih besar dari 0,05 . Selain menggunakan SPSS 16.0 perhitungan uji normalitas juga dilakukan 
dengan menggunakan Ms. Excel 2010 dengan rumus Chi-Square. Uji homogenitas data juga dilakukan dengan menggunakan Ms. Excel 2010 dengan menggunakan rumus sebagai berikut.

$$
\mathrm{F}_{\text {hit }}=\frac{S_{1}^{2}}{S_{2}^{2}}
$$

Keterangan:

$$
\begin{array}{ll}
\mathrm{S}_{1}{ }^{2} & =\text { varians terbesar } \\
\mathrm{S}_{2}{ }^{2} & =\text { varians terkecil } \\
3 . & \text { Uji Hipotesis }
\end{array}
$$

Untuk menguji hipotesis dengan menggunakan uji-t. Uji ini digunakan untuk menguji hasil posttest kelompok eksperimen dan kelompok kontrol. Uji-t yang digunakan pada penelitia ini yaitu polled varians.

Rumus Polled Varians:

$$
\mathrm{t}=\frac{\bar{X}_{1}-\bar{X}_{2}}{\sqrt{\frac{\left(n_{1}-1\right) S_{1}^{2}+\left(n_{2}-1\right) S_{2}^{2}}{n_{1}+n_{2}-2}\left(\frac{1}{n_{1}}+\frac{1}{n_{2}}\right)}}
$$

Keterangan:

$\bar{X}_{1} \quad=$ nilai rata-rata skor kelompok eksperimen

$\bar{X}_{2} \quad=$ nilai rata-rata skor kelompok kontrol

$\mathrm{n}_{1} \quad$ = banyaknya siswa kelompok eksperimen

$\mathrm{n}_{2} \quad=$ banyaknya siswa kelompok kontrol

$\mathrm{S}_{1}{ }^{2} \quad=$ varians kelompok eksperimen

$\mathrm{S}_{2}{ }^{2} \quad=$ varians kelompok kontrol

Untuk mendapat hasil yang lebih akurat analisis uji-t dilakukan dengan dua cara, yaitu cara manual dan dengan bantuan program SPSS PC 16.0 for Windows. Apabila cara manual untuk menghasilkan interpretasi, maka thitung tersebut harus dikomparasikan dengan tabel dengan indikator taraf signifikan $5 \%(0,05)$. Apabila thitung lebih besar daripada tabel (thitung $>$ tabel), maka terdapat perbedaan yang signifikan anatara kedua variabel atau sampel. Sedangkan apabila thitung lebih kecil dari tabel (thitung $<$ tabel), maka tidak terdapat perbedaan yang signifikan antara kedua variabel atau sampel. Angka signifikan lebih kecil dari 0,05 berarti $\mathrm{H}_{0}$ ditolah dan artinya terdapat perbedaan variabel bebas antar kelompok menurut sumber.

\section{Teknik Analisis Deskriptif Respon Siswa}

Respon siswa terhadap penggunaan media pembelajaran e-learnig schoology dikumpulkan dengan menggunakan angket respon siswa. Angket yang digunakan adalah angket skala likert dengan pilihan Sangat Setuju (SS), Setuju (S), Kurang Setuju (KS), Tidak Setuju (TS), dan Sangat Tidak Setuju (STS), sedangkan untuk respon negatif pemberian skor terbalik dengan item positif. Untuk mencari rata-rata atau mean $(\bar{X})$ dapat dilakukan dengan rumus berikut.

$$
\bar{X}=\frac{\sum X}{N}
$$

Keterangan:

$$
\begin{array}{ll}
\sum_{\bar{N}} \mathrm{X} & =\text { skor rata-rata respon belajar } \\
\mathrm{N} & =\text { banlah skor respon belajar } \\
&
\end{array}
$$

Untuk kriteria pemberian skor respon siswa terdapat dalam Tabel 2.

Tabel 2. Kriteria Pemberian Skor Respon Siswa

\begin{tabular}{lcc}
\hline \multicolumn{1}{c}{ Analisis Jawaban } & \multicolumn{2}{c}{ Nilai Item } \\
& Positif & Negatif \\
\hline Sangat Setuju & 5 & 1 \\
Setuju & 4 & 2 \\
Kurang Setuju & 3 & 3 \\
Tidak Setuju & 2 & 4 \\
Sangat Tidak Setuju & 1 & 5 \\
\hline
\end{tabular}

Data skor respon siswa kemudian dikategorikan sesuai dengan pedoman pada Tabel 3 berikut. 
Tabel 3. Kategori Respon Siswa

\begin{tabular}{cc}
\hline Rentang Skor & Kategori \\
\hline $\mathrm{Mi}+1,5 \mathrm{Sdi} \leq \bar{X}$ & Sangat Positif \\
$\mathrm{Mi}+0,5 \mathrm{Sdi} \leq \bar{X}<\mathrm{Mi}+1,5 \mathrm{Sdi}$ & Positif \\
$\mathrm{Mi}-0,5 \mathrm{Sdi} \leq \bar{X}<\mathrm{Mi}+0,5 \mathrm{Sdi}$ & Cukup Positif \\
$\mathrm{Mi}-1,5 \mathrm{Sdi} \leq \bar{X}<\mathrm{Mi}-0,5 \mathrm{Sdi}$ & Kurang \\
$\bar{X}<\mathrm{Mi}-1,5 \mathrm{Sdi}$ & Sangat Kurang \\
\hline
\end{tabular}

\section{HASIL DAN PEMBAHASAN}

1. Hasil Penelitian

Penelitian eksperimen ini bertujuan untuk mencari pengaruh penggunaan E-learning Schoology terhadap hasil belajar Pemrograman Web dan Perangkat Bergerak siswa kelas XI RPL. Setelah diberikan perlakuan, selanjutnya diberikan tes akhir (posttest) pada kelompok eksperimen dan kelompok kontrol dengan tujuan untuk mengetahui hasil belajar siswa setelah diberi perlakuan. Analisis dari hasil penelitian didapat bahwa rata-rata posttest hasil belajar pemrograman web dan perangkat bergerak yang dicapai siswa pada kelompok eksperimen yang menggunakan e-learning schoology pada proses pembelajaran adalah sebesar 32,72 dengan varians 8,06 dan standar deviasi sebesar 2,84 dengan distribusi nilai seperti pada Gambar 2 berikut.

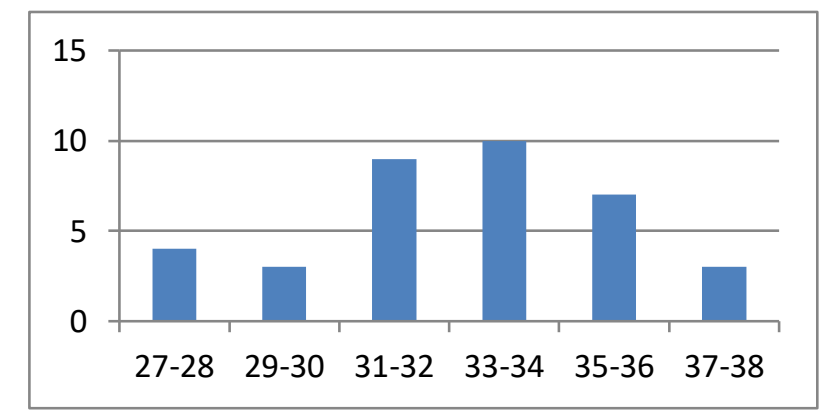

Gambar 2. Grafik Hasil Posttest Kelompok Eksperimen

Histogram pada Gambar 2 dapat dijelaskan sebagai berikut. Sebanyak 7 siswa (20.59\%) memiliki skor antara 23-24, sebanyak 7 siswa (20.59\%) memiliki skor 25-26, sebanyak 7 siswa (20.59\%) memiliki skor 27-28, sebanyak 8 siswa (23,53\%) memiliki skor 29-30, sebanyak 1 siswa (2.94\%) memiliki skor 31-32, dan sebanyak 4 siswa (11.76\%) memiliki skor 33-34. Berdasarkan distribusi nilai pada kelas eksperimen, maka kategori nilai pada kelas eksperimen dapat dikelompokkan sesuai dengan kategori pada Gambar 3 berikut.

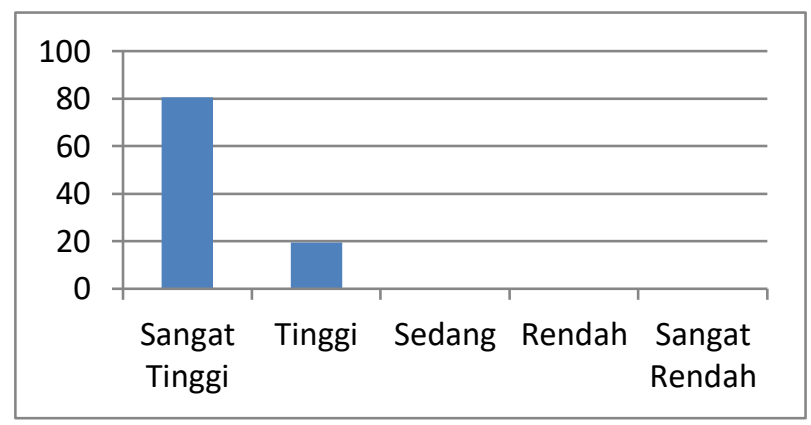

Gambar 3. Kategori Skor Posttest Kelas Eksperimen

Pada Gambar 3 dapat diketahui bahwa hasil belajar pemrograman web dan perangkat bergerak kelompok eksperimen sebanyak 29 siswa (80.56\%) berkategori sangat tinggi, sebanyak 7 siswa (19.44\%) berkategori tinggi, serta tidak ada siswa yang memiliki hasil belajar pemrograman web dan perangkat bergerak berkategori sedang, rendah dan sangat rendah.

Hasil analisis nilai posttest kelompok kontrol mendapat rata 27,56 dengan varians sebesar 10,06 dan standar deviasi sebesar 3,17 dengan distribusi nilai seperti pada Gambar 4 berikut. 


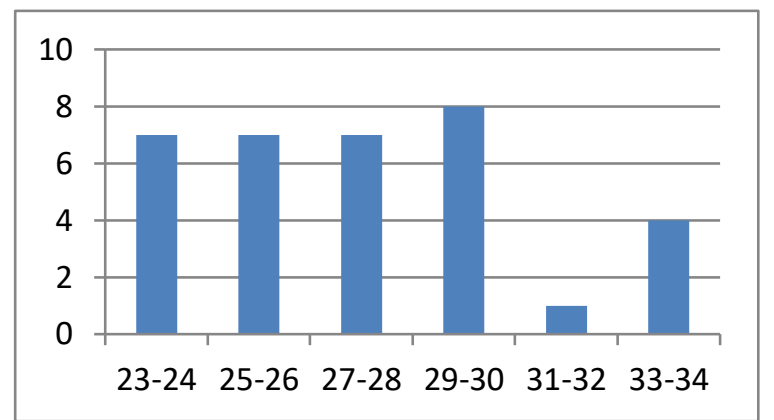

Gambar 4. Grafik Hasil Posttest Kelompok Kontrol

Histogram pada Gambar 4 dapat dijelaskan sebagai berikut. Sebanyak 7 siswa $(20.59 \%)$ memiliki skor antara 23-24, sebanyak 7 siswa (20.59\%) memiliki skor 25-26, sebanyak 7 siswa (20.59\%) memiliki skor 27-28, sebanyak 8 siswa (23,53\%) memiliki skor 29-30, sebanyak 1 siswa (2.94\%) memiliki skor $31-32$, dan sebanyak 4 siswa (11.76\%) memiliki skor 33-34. Berdasarkan distribusi nilai pada kelas eksperimen, maka kategori nilai pada kelas eksperimen dapat dikelompokkan sesuai dengan kategori pada Gambar 5 berikut.

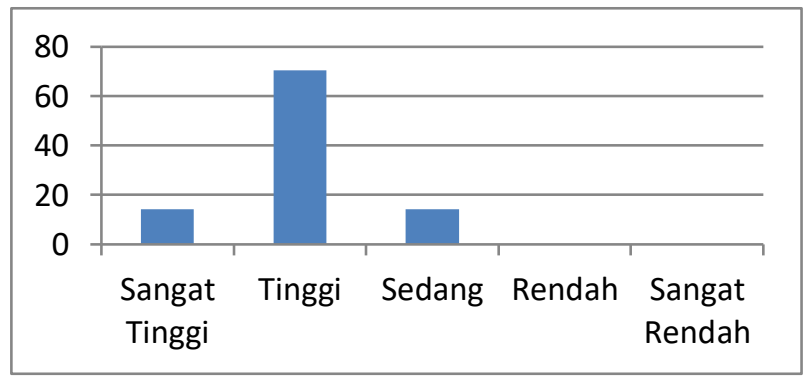

Gambar 5. Kategori Skor Posttest Kelas Kontrol

Pada Gambar 5 dapat diketahui bahwa hasil belajar pemrograman web dan perangkat bergerak kelompok kontrol sebanyak 5 siswa (14.71\%) berkategori sangat tinggi, sebanyak 24 siswa (70.59\%) berkategori tinggi, sebanyak 5 siswa $(14.71 \%)$ berkategori sedang, serta tidak ada siswa yang memiliki hasil belajar pemrograman web dan perangkat bergerak berkategori rendah dan sangat rendah.

Perhitungan uji prasyarat dilakukan dalam dua buah uji yakni normalitas dan homogenitas. Uji normalitas data hasil belajar dilakukan dengan dua jenis perhitungan yaitu dengan menggunakan Ms. Excel 2010 dan menggunakan SPSS 16.0. Hasil belajar kelompok eksperimen dengan melakukan perhitungan pada Ms. Excel 2010 mendapat hasil $x^{2}$ hitung sebesar 3,45171 dan kelompok kontrol mendapat hasil $x^{2}$ hitung sebesar 9,11155 . $x^{2}$ tabel dengan $d k=(6-1)=5$ dan taraf signifikan $5 \%$ adalah sebesar 11,070, dengan demikian data kelas eksperimen dan kelas kontrol dinyatakan berdistribusi normal karena $\mathrm{x}^{2}$ hitung $<\mathrm{x}^{2}$ tabel yang ditunjukkan pada Tabel 2 berikut.

Tabel 2. Rangkuman Hasil Uji Normalitas dengan Ms. Excel 2010

\begin{tabular}{ccccc}
\hline No & Sampel & $\mathbf{X}^{2}$ hitung & $\mathbf{X}^{2}$ tabel & Keterangan \\
\hline 1. & Kelompok Eksperimen & 3.45171 & 11.070 & Normal \\
2. & Kelompok Kontrol & 9.11155 & 11.070 & Normal \\
\hline
\end{tabular}

Selain menggunakan Ms. Excel 2013 perhitungan uji normalitas juga dilakukan dengan menggunakan SPSS 16.0 dengan hasil seperti pada Tabel 3 berikut.

Tabel 3. Rangkuman Hasil Uji Normalitas dengan SPSS 16.0

\begin{tabular}{ccccc}
\hline Kelompok & $\begin{array}{c}\text { Kolmogorov- } \\
\text { Smirnov }\end{array}$ & $\begin{array}{c}\text { Shapiro- } \\
\text { Wilk }\end{array}$ & Sig & Keterangan \\
\hline Eksperimen & 0,200 & 0,328 & 0,05 & Normal \\
Kontrol & 0,200 & 0,091 & 0,05 & Normal \\
\hline
\end{tabular}


Hasil uji normalitas menggunakan SPSS 16.0 menunjukkan bahwa angka signifikan kelompok eksperimen dan kelompok kontrol lebih besar dari 0,05 sehingga kedua data hasil belajar tersebut dikatakan berdistribusi normal.

Perhitungan selanjutnya adalah uji homogenitas menggunakan uji-f sehingga mendapat hasil $F_{\text {hitung }}=1,248$. Derajat kebebasan $(\mathrm{dk})$ untuk pembilang adalah $34-1=33$ dan derajat kebebasan (dk) untuk penyebut adalah $36-1=35$ dengan taraf signifikan (a) $5 \%$, maka diperoleh $\mathrm{F}_{\text {tabel }}=1.77$. Dalam hal ini berlaku ketentuan, bila harga $F_{\text {hitung }}$ lebih kecil atau sama dengan $F_{\text {tabel }}\left(F_{\text {hitung }} \leq F_{\text {tabel }}\right)$, maka $\mathrm{H}_{0}$ diterima dan $\mathrm{H}_{1}$ ditolak sehingga varians dikatakan homogen. Karena nilai $\mathrm{F}_{\text {hitung }}<\mathrm{F}_{\text {tabel }}$ $(1.248<1.77)$ maka $\mathrm{H}_{0}$ diterima dan $\mathrm{H}_{1}$ ditolak. Selain itu, uji homogenitas juga dilakukan dengan SPSS 16.0 dengan hasil 0,623 yang berarti homogeny karena lebih besar dari taraf signifikan yaitu 0,05 .

Berdasarkan data yang diperoleh kelompok eksperimen dan kelompok kontrol telah berdistribusi normal dan data homogen maka dilanjutkan dengan melakukan uji hipotesis dengan menggunakan uji-t. Uji-t dapat dihitung dengan menggunakan Ms. Excel 2010 dan SPSS 16.0. Uji-t dengan Ms. Excel 2010 dihitung menggunakan rumus Polled Varians sebagai berikut.

$$
\begin{aligned}
& \mathrm{t}=\frac{\bar{X}_{1}-\bar{X}_{2}}{\sqrt{\frac{\left(n_{1}-1\right) S_{1}^{2}+\left(n_{2}-1\right) S_{2}^{2}}{n_{1}+n_{2}-2}\left(\frac{1}{n_{1}}+\frac{1}{n_{2}}\right)}} \\
& \mathrm{t}=\frac{32.72-27.56}{\sqrt{\frac{(36-1) 8.06+(34-1) 10.06}{36+34-2}\left(\frac{1}{36}+\frac{1}{34}\right)}} \\
& \mathrm{t}=\frac{5.16}{0.7175}=7.1916
\end{aligned}
$$

Berdasarkan perhitungan tersebut memperoleh thitung sebesar 7,1916. Nilai tabel dengan dk 70$2=68$ dengan taraf signifikan $5 \%$ adalah sebesar 1,9955. Berdasarkan perhitungan uji-t diperoleh thitung $>$ tabel $(7.1916>1.9955)$ maka $\mathrm{H}_{0}$ ditolak, berarti $\mathrm{H}_{1}$ diterima. Berdasarkan hal ini dapat diartikan bahwa terdapat perbedaan hasil belajar yang lebih tinggi antara siswa yang belajar menggunakan $e-$ learning schoology dengan siswa yang belajar tanpa menggunakan e-learning schoology pada mata pelajaran Pemrograman Web dan Perangkat Bergerak kelas XI RPL SMK Negeri 1 Negara. Uji-t juga dihitung dengan menggunakan SPSS 16.0 dengan hasil sebagai berikut.

Tabel 4. Uji Hipotesis dengan SPSS 16.0

\begin{tabular}{clcccc}
\hline & & \multicolumn{3}{c}{ t-test for Equality of Means } \\
& & $\mathrm{t}$ & $\mathrm{Df}$ & $\begin{array}{c}\text { Sig. } \\
\text { (2tailed) }\end{array}$ \\
\hline \multirow{3}{*}{ Nilai } & $\begin{array}{l}\text { Equal variances assumed } \\
\text { Equal variances not }\end{array}$ & 7.172 & 68 & .000 \\
& $\begin{array}{l}\text { Eqsumed } \\
\text { assumen }\end{array}$ & 7.159 & 67.002 & .000 \\
\hline
\end{tabular}

Hasil uji hipotesis dengan uji-t menggunakan SPSS 16.0 didapatkan nilai signifikan sebesar 0,000 . Oleh karena itu probabilitas signifikan $<0,05$, maka $\mathrm{H}_{0}$ diterima, sehingga dapat dikatakan bahwa terdapat pengaruh yang signifikan penggunaan e-learning schoology dalam proses pembelajaran.

Hasil analisis respon siswa mendapat rata 84,72 yang termasuk kekategori sangat positif dengan distribusi nilai seperti pada Gambar 5 berikut.

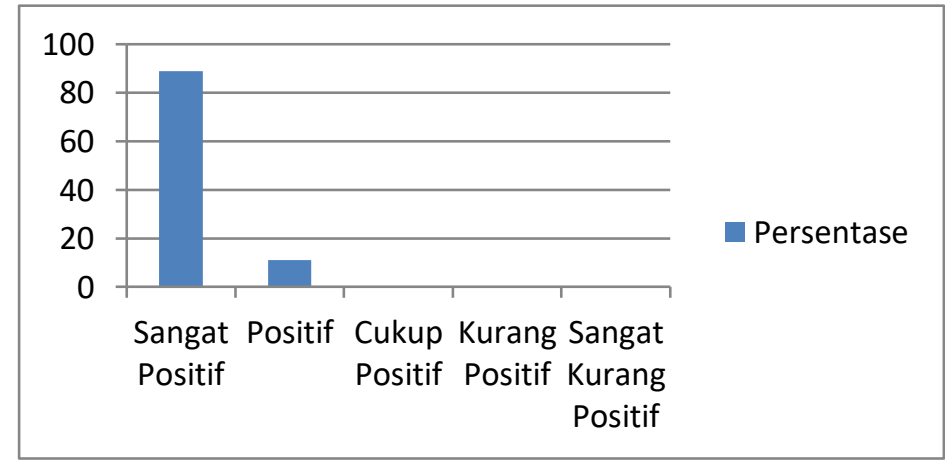

Gambar 5. Grafik Respon Siswa 
Histogram pada Gambar 5 dapat dijelaskan sebagai berikut. Sebanyak 89\% berkategori sangat positif, sebanyak $11 \%$ berkategori positif, serta tidak ada siswa yang respon siswa terhadap $e-$ learning schoology pada mata pelajaran pemrograman web dan perangkat bergerak berkategori cukup positif, kurang positif dan sangat kurang positif.

\section{Pembahasan}

a. Hasil Belajar

Berdasarkan seluruh penemuan yang diperoleh baik dari analisis deskriptif maupun berdasarkan hasis analisis uji-t, maka dapat diambil suatu keputusan bahwa e-learning schoology memberikan pengaruh yang lebih baik dibandingkan dengan pembelajaran tanpa menggunakan $e-$ learning schoology.

Berdasarkan pertimbangan teoritik dan operasional, maka implikasi dari penelitian ini jika dilihat dari teori belajar konstruktivisme adalah siswa membangun sendiri pengetahuannya, dalam proses pembelajaran di kelas siswa harus terlibat aktif dan siswa menjadi pusat kegiatan belajar dan pembelajaran di kelas. Siswa harus dapat melakukan pengaturan diri dalam belajar (self regulated learning). Proses pembelajaran dengan self regulated learning menjadikan siswa menjadi lebih mandiri, dapat mengaplikasikan ide-ide mereka sendiri, mendapat pengalaman berhipotesis, mencari jawaban, berimajinasi dan menemukan dalam upaya mengembangkan konstruksi-konstruksi baru, serta dapat mengevaluasi kemampuan belajarnya sendiri, sehingga pencapaian hasil belajar menjadi lebih baik untuk meningkatkan hasil belajar.

\section{b. Respon Siswa}

Hasil analisis respon siswa terhadap penerapan e-learning schoology dalam pembelajaran pemrograman web dan perangkat bergerak termasuk dalam kategori sangat positif. Keadaan seperti ini dapat dijadikan modal untuk menciptakan suasana belajar yang efektif agar bisa meningkatkan hasil belajar siswa yang lebih tinggi. Jadi dengan diperoleh respon siswa yang sangat positif terhadap penggunaan e-learning schoology dalam mata pelajaran pemrograman web dan perangkat bergerak maka dapat disimpulkan bahwa penggunaan e-learning schoology memberikan pengaruh yang lebih baik dibandingkan dengan kelas yang menggunakan bahan ajar power point dan dapat diterima baik oleh siswa. Inti pembelajaran dengan e-learning schoology yaitu dimana e-learning schoology dirancang agar siswa bisa lebih mandiri dan aktif dalam proses pembelajaran, sehingga proses belajar di kelas menjadi terstruktur dan terarah.

\section{SIMPULAN DAN SARAN}

Berdasarkan paparan hasil penelitian dan pembahasan dapat disimpulkan sebagai berikut. 1) belajar menggunakan e-learning schoology pada mata pelajaran pemrograman web dan perangkat bergerak kelas XI RPL di SMK Negeri 1 Negara memiliki hasil belajar yang lebih tinggi dengan siswa yang belajar tanpa menggunakan e-learning schoology. Hal ini dapat dilihat dari hasil pengujian hipotesis menggunakan analisis uji-t dimana thitung $=7.1916>$ dari tabel $=1.9955$ maka $\mathrm{H}_{0}$ ditolak atau $\mathrm{H}_{1}$ diterima. 2) Hasil analisis respon siswa dari penggunaan e-learning schoology pada mata pelajaran pemrograman web dan perangkat bergerak adalah sangat positif dilihat dari rata-rata skor hasil angket respon siswa yaitu sebesar 84.72 .

Berdasarkan hasil penlitian dapat diajukan beberapa saran guna meningkatkan kualitas pembelajaran Pemrograman Web dan Perangkat Bergerak yaitu sebagai berikut: 1) Kepada peneliti lain yang membaca penelitian ini dan bermaksud mengembangkan hasil temuan lebih lanjut, diharapkan dapat melakukan penelitian yang lebih baik dengan cara menggunakan sampel yang lebih banyak, seperti diterapkan di sekolah lain pada mata pelajaran yang sama, sehingga hasilnya akan lebih luas dan lebih terukur keakuratannya. 2) E-learning Schoology yang digunakan dalam penelitian ini belum sepenuhnya dapat digunakan dengan baik oleh guru maupun siswa, dikarenakan masih ada beberapa menu yang belum dipahami cara penggunaannya. Peneliti menyarankan bagi peneliti lain yang ingin mengembangkan media pembelajaran berupa e-learning schoology agar membuatkan sebuah pedoman penggunaan e-learning schoology secara lengkap sebagai media dalam pembelajaran baik yang ditujukan kepada guru maupun kepada siswa itu sendiri.

\section{DAFTAR PUSTAKA}

[1] Hakim, T. (2005). Belajar Secara Efektif. Jakarta: Pustaka Pembangunan Swadaya Nusantara.

[2] Sadiman et.al. (2005). Media Pendidikan. Jakarta: PT Raja Grafindo Persada.

[3] Belawati, T. (2006). Pengembangan Bahan Ajar. Jakarta: Universitas Terbuka. 
[4] Sugihartini, N., \& Agustini, K. (2017). Asesmen Otentik Sebagai Pendukung Desain dengan Pendekatan Konstruktivistik. Journal of Education Action Research.

[5] Prawiladilaga, D., \& Siregar, E. (2007). Mozaik Teknologi Pendidikan. Jakarta: Kencana.

[6] Munir. (2009). Pembelajaran Jarak Jauh: Berasis Teknologi Informasi dan Komunikasi. Bandung: CV. Alvabeta.

[7] Azizah, S. R. (2017). Pengaruh Penggunaan E-Learning Dengan Schoology Terhadap Hasil Belajar Siswa.

[8] Sugiyono. (2014). Metode Penelitian Pendidikan Pendekatan Kuantitatif, Kualitatif dan R\&D. Bandung: Alfabeta.

[9] Gregory, R. J. (2000U). Phsycological Testing. nited States of America: Allyn \& Bacon Inc.

[10] Candiasa, I. M. (2011). Pengujian Instrumen Penelitian Disertai Aplikasi Iteman dan Bigsteps. Singaraja: Unit Penerbit Undiksha.

[11] Arikunto, S. (2005). Managemen Penelitian . Jakarta: PT Rineka Cipta.

[12] Sugiarto, S. R (2018). Pengembangan E-Modul Mata Pelajaran Photography Berbasis Project Based Learning Kelas XI Di SMK TI Bali Global Singaraja. Kumpulan Artikel Mahasiswa Jurusan Pendidikan Teknik Informatika.

[13] Nasution, S. (2001). Berbagai Pendekatan dalam Proses Belajar Mengajar. Jakarta: Bali Aksara.

[14] Arsyad. (2011). Media Pembelajaran. Jakarta: Rajawali.

[15] Daryanto. (2005). Evaluasi Pendidikan. Jakarta: Rineka Cipta.

[16] Rusman. (2010). Model-Model Pembelajaran. Jakarta: Raja Grafindo.

[17] Mudjiono, D. (2006). Belajar dan Pembelajaran. Jakarta: Rineka Cipta. 